Article

\title{
Anti-Coagulant and Antimicrobial Recombinant Heparin-Binding Major Ampullate Spidroin 2 (MaSp2) Silk Protein
}

\author{
Pranothi Mulinti ${ }^{1,+}+\left(\mathbb{D}\right.$, Dorina Diekjürgen ${ }^{2,+}$, Kristen Kurtzeborn ${ }^{2}$, Narayanaganesh Balasubramanian ${ }^{3}$, \\ Shane J. Stafslien ${ }^{4}$, David W. Grainger ${ }^{2,5}$ and Amanda E. Brooks $1,2,6, * \mathbb{D}$
}

check for

updates

Citation: Mulinti, P.; Diekjürgen, D.; Kurtzeborn, K.; Balasubramanian, N.; Stafslien, S.J.; Grainger, D.W.; Brooks, A.E. Anti-Coagulant and Antimicrobial Recombinant Heparin-Binding Major Ampullate Spidroin 2 (MaSp2) Silk Protein. Bioengineering 2022, 9, 46. https://doi.org/10.3390/ bioengineering 9020046 Academic Editor: Rajesh Naik

Received: 1 December 2021 Accepted: 14 January 2022 Published: 19 January 2022

Publisher's Note: MDPI stays neutral with regard to jurisdictional claims in published maps and institutional affiliations.

Copyright: (C) 2022 by the authors. Licensee MDPI, Basel, Switzerland. This article is an open access article distributed under the terms and conditions of the Creative Commons Attribution (CC BY) license (https:// creativecommons.org/licenses/by/ $4.0 /)$.
1 Department of Pharmaceutical Sciences, North Dakota State University, Fargo, ND 58105, USA; pranothimulinti@gmail.com

2 Department of Pharmaceutics and Pharmaceutical Chemistry, University of Utah, Salt Lake City, UT 84132, USA; Dorina.diekjuergen@utah.edu (D.D.); kurtzebornk@gmail.com (K.K.); david.grainger@utah.edu (D.W.G.)

3 Proteomics, Metabolomics and Mass Spectrometry, North Dakota State University, Fargo, ND 58105, USA; b.narayanaganesh@gmail.com

4 Coatings and Polymeric Materials, North Dakota State University, Fargo, ND 58105, USA; shane.stafslien@ndsu.edu

5 Department of Biomedical Engineering, University of Utah, Salt Lake City, UT 84112, USA

6 Department of Molecular Biology, Rocky Vista University, Ivins, UT 84738, USA

* Correspondence: abrooks@rvu.edu

+ These authors contributed equally to this work.

\begin{abstract}
Governed by established structure-property relationships, peptide motifs comprising major ampullate spider silk confer a balance of strength and extensibility. Other biologically inspired small peptide motifs correlated to specific functionalities can be combined within these units to create designer silk materials with new hybrid properties. In this study, a small basic peptide, (ARKKAAKA) known to both bind heparin and mimic an antimicrobial peptide, was genetically linked to a protease-resistant, mechanically robust silk-like peptide, MaSp2. Purified fusion proteins (four silk domains and four heparin-binding peptide repeats) were expressed in E. coli. Successful fusion of a MaSp2 spider silk peptide with the heparin-binding motif was shown using a variety of analytical assays. The ability of the fusion peptide to bind heparin was assessed with ELISA and was further tested for its anticoagulant property using aPTT assay. Its intrinsic property to inhibit bacterial growth was evaluated using zone of inhibition and crystal violet $(\mathrm{CV})$ assays. Using this strategy, we were able to link the two types of genetic motifs to create a designer silk-like protein with improved hemocompatibility and antimicrobial properties.
\end{abstract}

Keywords: spider silk; heparin binding peptides; recombinant protein expression; functional heparin assay; fusion protein

\section{Introduction}

A hierarchical structure rooted in the biochemical composition of two main proteins, MaSp1 and MaSp2, gives major ampullate spider silk an impressive balance of strength and elasticity, unrivaled by synthetic materials [1,2]. Phylogenetic analyses of major ampullate silk sequences, in addition to other proteomic [3] and structural analyses [4,5], revealed evolutionarily conserved repetitive amino acid motifs subsequently correlated with specific structural and functional features of the silk [6]. These correlative conclusions have been well-studied by producing clones of simplified monomer motifs [4,7-9] to identify and establish overarching structure-property relationships [6,10]. In addition to mechanical properties that can be manipulated by genetically combining functional motifs, several recombinant spider silk fusion proteins have been explored to date (i.e., silk-uranium 
binding proteins [11], silk-antibiotic [12], silk-silica binding proteins [13,14], silk-bone sialoprotein [15], silk-elastin [16] etc.). Alternatively, spider silk protein was also recently chemically complexed with heparin and chitosan to create an anticoagulant, antimicrobial, dual-function protein [17]. This manuscript describes a new genetic modification of silk designed to both capture circulating heparin and provide intrinsic antimicrobial properties (Figure 1).

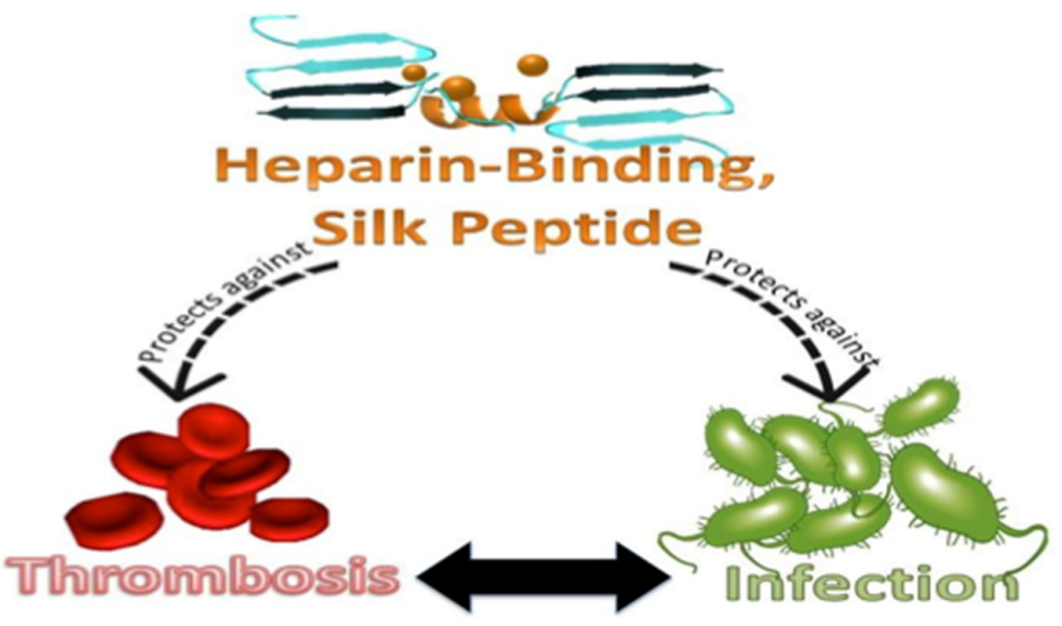

Figure 1. Infection and thrombosis are intimately connected. This is of particular concern for hemodialysis catheters and other blood-contacting medical devices. Using the naturally occurring heparin-binding motif (HBM) with the silk peptide can both bind heparin to alter coagulation and provide antimicrobial properties, ultimately improving blood compatibility and limiting infection risks.

Heparin, a hydrophilic, highly sulfonated, negatively charged polysaccharide copolymer comprised of glucosamine and glucuronic acid, is endogenously found in the human body (approximately $20 \mu \mathrm{g} / \mathrm{mL}$ in adult plasma). It is also commonly used as an extracorporeal anticoagulant at therapeutic concentrations over $50 \mathrm{nM}[18,19]$. Importantly, heparin is naturally bound to a diverse family of heparin-binding proteins based largely on electrostatic interactions [20-22]. Positively charged basic amino acid residues in the consensus Heparin Binding amino acid Motif (HBM) of these proteins interacts through ionic and hydrogen bonds with the strong negatively charged sulfate and carboxylate groups on the heparin polysaccharide $[20,23]$. Furthermore, the tertiary structure of the $\mathrm{HBM}$ is analogous to the overall structure $(\mathrm{XBBBXXBX}$, where $\mathrm{X}$ is a hydrophobic or uncharged amino acid and $B$ is a basic amino acid) of an antimicrobial peptide (AMP) [24,25]. Consequently, previous work has sought to exploit surface-bound HBM to create heparinized surfaces [26,27]. These efforts were able to successfully bind solution-phase heparin, with the best binding affinity based on four concatenated repeats of the synthetic motif (ARKKAAKA, $K_{D}=42 \pm 15 \mathrm{~nm}$ ) [27]. Importantly, this general peptide sequence is analogous to the LL-37 antimicrobial peptide, which is sensitive to proteolysis by human neutrophil-produced elastase as well as P. aeruginosa elastase, S. aureus V8 metalloproteinase and aureolysin [28]. Accordingly, bound heparin bioactivity was shown to be reduced by proteolytic cleavage [26,29]; therefore, utilizing a heparin-binding motif as a surface capture agent for circulating heparin necessitates embedding the protease-susceptible peptide into a protective polymer background. A biological and structural biopolymer, such as major ampullate spider silk, exhibiting no similar protease sensitivities may provide a suitable background to afford stability and permit heparin capture. In this context, we sought to genetically embed a small heparin-binding amino acid motif (HBM) into a recombinant silklike protein [30-33], ultimately creating a genetic chimera with new biomaterial properties (conceptually described in Figure 1).

Although many other biologically active silk fusion proteins have been explored [34] (e.g., antibiotics [12,35], chitosan [17], elastin [16], silica [13,14,36], RGD [37]), the combination reported here is a unique embodiment. Four concatenated repeats of the heparin- 
binding motif, ARKKAAKA, were genetically linked with MaSp2 amino acid motifs $\left(\right.$ GPGXXA $_{n}$ ) to produce a mechanically robust protein capable of both (1) binding biologically active heparin and (2) resisting pathogen colonization was produced, potentially enabling both in vivo anticoagulation and anti-infectivity [38]. The anti-coagulant activity of this fusion protein was comparable to the activity of surface-bound heparin. Here we report the design, production, and characterization of a new recombinant silk fusion protein with the ability to bind heparin and resist bacterial adhesion and growth.

\section{Materials and Methods}

Protein Expression and Purification

The complete genetic sequence of either two repeats of silk (SX2) or four repeats of silk linked with four repeats of HBM (S4H4) were designed, synthesized by GenScript (Piscataway, NJ, USA), and cloned into pET 30a for expression (Table 1).

Table 1. Amino acid sequences of the two expressed clones. Silk monomers are separated by lines while HBM component are shown in bold.

\begin{tabular}{l|l}
\hline SX2 & $\begin{array}{l}\text { GGYGPGQQGPGGYGPGQQGPSGPGSAAAAAAAA I GGYGPGQQGPGGYGPGQQGPSGPGSA } \\
\text { AAAAAAA }\end{array}$ \\
\hline S4H4 & GGYGPGQQGPGGYGPGQQGPSGPGSAAAAAAAA I GGYGPGQQGPGGYGPGQQGPSGPGSA \\
& AAAAAAA I GGYGPGQQGPGGYGPGQQGPSGPGSAAAAAAAA I GGYGPGQQGPGGYGPGQ \\
& QGPSGPGSAAAAAAAA I \\
ARKKAAKA ARKKAAKA ARKKAAKA ARKKAAKA \\
\hline
\end{tabular}

All proteins were expressed in E. coli BL21(DE3) pLysS cells (Promega, Fitchburg, MA, USA). Cultures were grown by shaking (220 rpm) at $37^{\circ} \mathrm{C}$ in Luria broth (LB) containing $100 \mu \mathrm{g} / \mathrm{mL}$ kanamycin to an $\mathrm{OD}_{600}$ between 0.8 and 1.0. Isopropyl- $\beta-\mathrm{D}-1-$ thiogalactopyranoside (IPTG, Sigma-Aldrich, St. Louis, MI, USA) was added at a final concentration of $1 \mathrm{mM}$ to induce protein expression. After $2 \mathrm{~h}$, the culture was centrifuged at $8000 \mathrm{rpm}$ for $10 \mathrm{~min}$, and the media was decanted. Cell pellets were resuspended in $100 \mathrm{mM}$ HEPES buffer (1/10 of the final culture volume). To achieve better yields and higher purity, $50 \mu \mathrm{g} / \mathrm{mL}$ DNase I (Sigma-Aldrich) and $1 \mu \mathrm{L}$ of protease inhibitor cocktail (Sigma-Aldrich) was added per $100 \mathrm{~mL}$ of harvested culture prior to sonication (30 s at $40 \%$ power) and purification. Proteins were purified using nickel affinity chromatography. To identify the highest yield clones from each construct, the Maxwell ${ }^{\circledR} 16$ Polyhistidine Protein Purification system (Promega) was used according to the manufacturer's instructions for the prefilled nickel affinity reagent cartridge (Promega) [39]. Purified protein was dialyzed against water overnight and lyophilized [40].

\section{Protein Characterization}

\subsection{Sodium Dodecyl Sulfate Polyacrylamide Gel Electrophoresis (SDS-PAGE)}

Purified proteins were analyzed for size and purity by SDS-PAGE. Solution from each well of the Maxwell purification cartridge was analyzed to assess the efficacy of the purification. Each sample was briefly $(<5 \mathrm{~min})$ heated with NuPAGE LDS sample buffer (Invitrogen, Waltham, MI, USA) at $95{ }^{\circ} \mathrm{C}$ and then loaded into a precast Bis-tris $4-12 \%$ Polyacrylamide gradient gel (Invitrogen). The gel was run in MES buffer at $150 \mathrm{~V}$ for $45 \mathrm{~min}$. Protein bands were visualized on a BioRad Chemidoc XRS imaging system after staining with AcquaStain Protein Gel Stain (Bulldog Bio. Inc, Portsmouth, NH, USA).

\subsection{Western Blot}

The identity of purified protein products was confirmed via western blotting. Purified proteins were run on a denaturing SDS-PAGE and transferred to a nitrocellulose membrane at $40 \mathrm{~V}$ for $60 \mathrm{~min}$ using a standard transfer protocol for semi dry blotting [41]. After proteins were transferred to the nitrocellulose membrane using Invitrogen's Xcell ${ }^{\mathrm{TM}}$ Blot Module, the SNAPi.d. protein detection system (Milliporesigma, St. Louis, MI, USA) was used for immune detection with a 1:4000 dilution of a HRP-conjugated 6x-His Epitope Tag 
Polyclonal Antibody (PA1-23024, ThermoFisher, Waltham, MI, USA) in Tris buffered saline plus Tween $20(0.05 \%)$ (Fisher, USA TBST, ionic strength $=175 \mathrm{mM})$. Amersham ${ }^{\mathrm{TM}} \mathrm{ECL}^{\mathrm{TM}}$ Prime Western blotting detection reagent (GE Healthcare Life Sciences, Chicago, IL, USA) was used according to manufacturer specifications, and the bands were visualized using the Bio-Rad ChemiDoc ${ }^{\mathrm{TM}}$, Hercules, USA XRS camera under varying exposure.

\subsection{Mass Spectrometry (MS)}

Mass spectrometry was performed at the Core Synthesis and Analytical Services Facility (Center for Protease Research, North Dakota State University, Fargo, ND, USA) on purified protein samples. Briefly, the intact mass analyses of the specific silk-like proteins was performed after desalting them followed by LC-MS analysis on a Waters Synapt G2-Si HDMS (Waters Corporation, Milford, CT, USA). UPLC was performed on an Acquity UPLC-I class with Waters BEH C18 $(2.1 \mathrm{~mm} \times 100 \mathrm{~mm}) 1.7 \mu \mathrm{m}$ column. The column was maintained at $35{ }^{\circ} \mathrm{C}$ throughout the analyses. A linear gradient was performed over $7 \mathrm{~min}$, shifting the ratio of $\mathrm{A}(0.1 \%$ formic acid in water $)$ to $\mathrm{B}(0.1 \%$ formic acid in acetonitrile $)$ from $90 / 10(\mathrm{~A} / \mathrm{B})$ to $10 / 90(\mathrm{~A} / \mathrm{B})$. The total gradient run was $13 \mathrm{~min}$. Desalted protein solution $(100 \mu \mathrm{L})$ was mixed with $200 \mu \mathrm{L}$ of $0.1 \%$ TFA in water/acetonitrile $(50 / 50)$ and $10 \mu \mathrm{L}$ was injected at a rate of $0.5 \mathrm{~mL} / \mathrm{min}$. Mass spectrometric analysis was performed on a Waters Synapt G2-Si HDMS. The collected mass spectrum data in continuum format were processed using MaxEnt1 software (Waters Corporation) to obtain the protein mass. The peak width parameter used to obtain the result was between 0.45 Da to 0.6 Da depending on the sample. Spectra were processed between 5000 to 50,000 Da at $1 \mathrm{Da} /$ channel.

\section{Heparin-Binding Characterization}

\subsection{Heparin Affinity Dot Blot}

Purified proteins (10 $\mu \mathrm{L}$ at approximately $100 \mu \mathrm{g} / \mu \mathrm{L})$ were applied to a nitrocellulose membrane (Sigma-Aldrich) and allowed to adsorb for $30 \mathrm{~min}$. The membrane was blocked on a rotating platform for $1 \mathrm{~h}$ in a blocking solution ( $5 \%$ non-fat instant milk) (Carnation, Los Angeles, CA, USA) in Tris buffered saline plus Tween 20 (0.05\%) (TBST, Fisher, USA) (ionic strength $=175 \mathrm{mM}$ ). The membrane was subsequently probed with biotinylated heparin (Sigma-Aldrich; from porcine intestinal mucosa, MW 15,000 Da, purity: >97\%) diluted at 1:100 in the blocking solution for $1 \mathrm{~h}$ on a rotating platform. After washing the membrane three times for $15 \mathrm{~min}$ each in TBST (approximately $75 \mathrm{~mL}$ ), the blot was probed with horseradish peroxidase (HRP)-tagged streptavidin (Fisher Scientific, Hampton, NH, USA) diluted 1:100 in the blocking solution for $1 \mathrm{~h}$ on a rotating platform. The membrane was washed again three times for $15 \mathrm{~min}$ each in TBST (approximately $75 \mathrm{~mL}$ ), and reacted with enhanced chemiluminescence reagents (Pierce, Rockford, IL, USA) for 5 min prior to imaging on an Aplegen Omega Lum G, San Francisco, USA over 5 min, acquiring images at varying exposure times. An equivalent amount of Interleukin-2 (IL-2, PeproTech, East Windsor, NJ, USA), documented to bind heparin [42], was used as positive control while BSA, with no documented ability to bind heparin, was used as the negative control for all assays $[43,44]$. IL-2 binding of heparin did not yield a positive result in ELISA (data not shown). Additionally, a separate blot was probed with secondary streptavidin-HRP (Horseradish Peroxidase) (ThermoFisher Scientific, Waltham, MA, USA) only using an analogous protocol without the addition of biotinylated heparin.

\subsection{Heparin Affinity ELISA}

An indirect ELISA was performed on protein samples with BSA and plain silk (SX2) as negative controls. Polystyrene microtiter plate wells $(n=3)$ were incubated with $100 \mu \mathrm{L}$ of protein samples at a concentration of $100 \mu \mathrm{g} / \mathrm{mL}$ in Tris buffer $(\mathrm{pH} 7.5)$ for $2 \mathrm{~h}$. After incubation, the wells were washed three times using TBST (0.05\% Tween) and blocked using 5\% milk in TBS for another hour. Plates were rinsed again with TBST three times. Subsequently, $100 \mu \mathrm{L}$ of biotinylated heparin (heparin-biotin sodium salt, MW 15,000 Da, Sigma Aldrich, St. Louis, MO, USA) at a concentration of $45 \mu \mathrm{g} / \mathrm{mL}$ diluted in TBST 
was added to each well and incubated for $1 \mathrm{~h}$. Wells were washed again with TBST three times before adding streptavidin conjugated with HRP at a dilution of 1:1000 as the secondary ligand and incubated for $1 \mathrm{~h}$. Wells were again washed, and $100 \mu \mathrm{L}$ of TMB substrate (Fisher Scientific) was added and allowed to incubate for $20 \mathrm{~min}$ at which time the reaction was stopped using $1 \mathrm{M} \mathrm{HCl}$, according to the manufacturer's instructions for the TMB substrate. Optical absorbance was read at $480 \mathrm{~nm}$ on an Epoch plate reader (Biotek, Winooski, VT, USA).

\subsection{APTT Coagulation Assay}

An activated partial thromboplastin time (aPTT) assay, which assesses the rate at which the complex of plasma clotting factors assembles to convert prothrombin to thrombin prior to clot formation, (APTT XL Pacific Homeostasis Assay, ThermoFisher,) was performed to indirectly assess blood coagulation in the presence of silk binding motifs SX2 and $\mathrm{S} 4 \mathrm{H} 4$ according to the manufacturer's protocol. Whole blood for the assay was collected from euthanized rats via cardiac puncture into a sodium citrate $(4 \% w / v)$ solution and immediately stored at $-80{ }^{\circ} \mathrm{C}$ for use. Blood was thawed and then centrifuged at $2000 \mathrm{rpm}$ for $10 \mathrm{~min}$ to separate the plasma. Initially, heparin was titrated into plasma to determine the amount needed to prevent citrate-treated plasma from clotting in the presence of calcium. Briefly, aqueous heparin (heparin sodium porcine mucosa, Sigma Aldrich) $(200 \mu \mathrm{L}$ per well), ranging from $50 \mu \mathrm{g} / \mathrm{mL}$ to $200 \mu \mathrm{g} / \mathrm{mL}$ (diluted in Tris buffered saline (TBS)) was incubated with plasma $(0.1 \mathrm{~mL})$ in each well $(\mathrm{n}=2)$ for $2 \mathrm{~h}$ at room temperature with shaking. Subsequently, $0.1 \mathrm{~mL}$ of APTT-XL reagent was added, and the reaction was incubated for $5 \mathrm{~min}$. Calcium chloride solution $(0.1 \mathrm{~mL}$ of $0.02 \mathrm{M})$ was added to initiate clot-like formation. The time required for the formation of the clot was recorded. Clot-like formation was visually assessed as an optical change in the transparency of the solution. Based on its ability to prevent clot formation during the titration, $100 \mu \mathrm{g} / \mathrm{mL}$ of heparin was used for all additional assessments. A similar protocol was followed to assess the coagulation of plasma in the presence of SX2 and $\mathrm{S} 4 \mathrm{H} 4$ with the exception that the wells $(n=4)$ were incubated with either SX2 or S4H4 proteins at a concentration of $200 \mu \mathrm{g} / \mathrm{mL}$ prior to the addition of heparin, plasma or both. After allowing the protein to attach to the surface for $2 \mathrm{~h}$, the protein-depleted solution was removed from the wells and the wells were rinsed with PBS three to five times and blocked with $0.5 \%$ milk in TBS for $30 \mathrm{~min}$. The wells were not allowed to completely dry. Subsequently, all wells were rinsed again three times with PBS, and $200 \mu \mathrm{L}$ of heparin $(100 \mu \mathrm{g} / \mathrm{mL}$ in TBS) was added to the wells and incubated for another $2 \mathrm{~h}$. After incubation, the wells were rinsed with PBS and activated thromboplastin time was assessed using the APTT-XL assay by adding clarified plasma $(0.1 \mathrm{~mL})$ and the APTT-XL reagent $(0.1 \mathrm{~mL})$. Silk and S4H4 without heparin were used as controls.

\section{Antibacterial Activity}

\subsection{Kirby Bauer Zone of Inhibition Assay}

Maxwell-purified S4H4 and SX2 protein solutions ( $300 \mu \mathrm{L}$ of $20 \mathrm{mg} / \mathrm{mL}, \sim 90 \%$ purity) were spotted on the surface of an LB agar plate (within $15 \mathrm{~min}$ ) previously streaked with $E$. coli (ATCC 12435). An equivalent amount of BSA was applied as a negative control. Only one protein was applied per agar plate with each protein spotted on 3 independent plates. The plates were incubated at $37^{\circ} \mathrm{C}$ overnight and the diameter of the zone of inhibition (ZOI) was measured using digital calipers.

\subsection{Biofilm Formation}

Biofilm formation was characterized for E. coli (ATCC 12435) using a multi-well plate methodology described previously $[45,46]$. Prior to bacterial inoculation, $0.5 \mathrm{~mL}$ of protein solution $(1 \mathrm{mg} / \mathrm{mL})$ was added to four wells of a 24 -well tissue culture polystyrene (TCPS) plate and incubated for $1 \mathrm{~h}$. The protein-depleted solution was removed and the wells were rinsed three times with $1.0 \mathrm{~mL}$ of PBS. Subsequently, an overnight culture of E. coli 
prepared in LB broth was rinsed three times in PBS, harvested via centrifugation, and diluted in PBS to an $\mathrm{OD}_{600}$ of 0.4 . The resulting suspension was used to prepare dilutions $\left(10^{7}-10^{8}\right.$ cells $\left./ \mathrm{mL}\right)$ in minimal media, M63 $\left(10 \mathrm{~g}\right.$ of $\left(\mathrm{NH}_{4}\right)_{2} \mathrm{SO}_{4}, 68 \mathrm{~g}$ of $\mathrm{KH}_{2} \mathrm{PO}_{4}, 2.5 \mathrm{mg}$ of $\mathrm{FeSO}_{4} \cdot 7 \mathrm{H}_{2} \mathrm{O}, 254 \mathrm{mg}$ of $\mathrm{MgSO}_{4} \cdot 7 \mathrm{H}_{2} \mathrm{O}$, pH-7) supplemented with $2 \mathrm{~g} / \mathrm{L}$ dextrose. Bacterial suspensions $(1 \mathrm{~mL})$ were added to well plates pretreated for $1 \mathrm{~h}$ with either S4H4 or SX2 protein solutions and incubated statically for $24 \mathrm{~h}$ at $37^{\circ} \mathrm{C}$ (PBS and blank plate were used as controls). The wells were rinsed three times with $1.0 \mathrm{~mL}$ of PBS and stained with $0.5 \mathrm{~mL}$ of crystal violet (CV) solution dye (Bioworld, Dublin, OH, USA) for $15 \mathrm{~min}$ at ambient laboratory conditions. Excess $\mathrm{CV}$ dye was removed by rinsing three times with $1.0 \mathrm{~mL}$ of water and the wells were dried for $1 \mathrm{~h}$. The CV dye was extracted in 33\% glacial acetic acid for $15 \mathrm{~min}$ to solubilize the dye bound to the biofilm. An aliquot of $150 \mu \mathrm{L}$ of the acetic acid extracts were transferred to a 96-well plate and optical absorbance was measured at $600 \mathrm{~nm}$ using a multi-well plate spectrophotometer (Tecan Safire 2, Tecan US Inc., Morrisville, NC, USA).

\section{Mechanical Testing of Silk Fibers}

After recombinant proteins were desalted via dialysis and subsequently lyophilized, they were resuspended in $100 \mu \mathrm{L}$ of hexafluoroisopropanol (HFIP) to create a viscous solution. The solution was manually extruded through a $22 \mathrm{G}$ needle into isopropanol to create fibers. The diameter and birefringence of the fibers were assessed under polarized light on a Nikon DMi8 microscope using a $10 \times$ objective at 5 places along each fiber's length. Images were analyzed using grey-scale image analysis in ImageJ (NIH). Diameter measurements were then averaged and reported with its standard deviation. Each fiber was mounted on a paper frame with cyanoacrylate glue and tensile tested (Instron 5962, Epsilon Tech, Jackson, WY, USA) at $2 \mathrm{~mm} / \mathrm{min}$ per a previously published method [41].

\section{Statistical Analysis}

Data are presented as mean \pm standard deviation (SD). Statistical interpretation was performed by using IBM SPSS. Statistically significant differences between the experimental groups were determined by using the Mann Whitney U test.

\section{Results}

The repetitive sequence of Argiope aurantia major ampullate spidroin 2 (MaSp2), one of the key structural spider silk proteins, was genetically linked with the consensus sequence for the heparin-binding motif (HBM) (Table 1 and Figure 2). MaSp2 (silk) and HBM sequences were designed and engineered not only to optimize expression in $E$. coli, but also to facilitate their genetic linkage and polymerization. All produced clones were screened via colony PCR and sequence confirmed by the University of Utah core sequencing facility (data not shown).

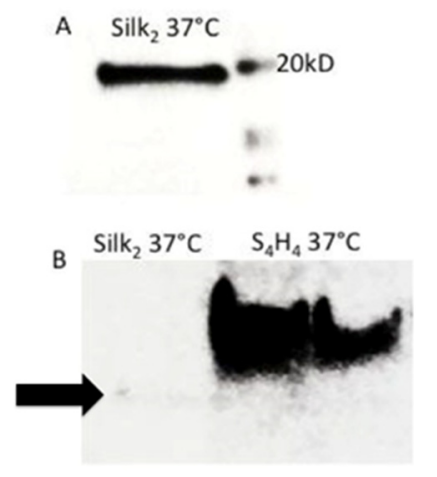

Figure 2. Western blots for (A) SX2 protein and (B) S4H4 (2 clones) using a HRP-conjugated anti-His antibody. Molecular weight markers are shown on SX2. Note that all gels were non-reducing. 
Subsequently, genetic constructs were PCR-cloned into pET30a for protein expression. Expression was induced in BL21-DE3 E. coli using IPTG. An average of $10 \mathrm{mg}$ protein was purified from $1 \mathrm{~L}$ of culture. Fusion protein production was confirmed by: (1) SDS-PAGE; (2) Western blot (Figure 2); and (3) mass spectrometry (Figure 3).

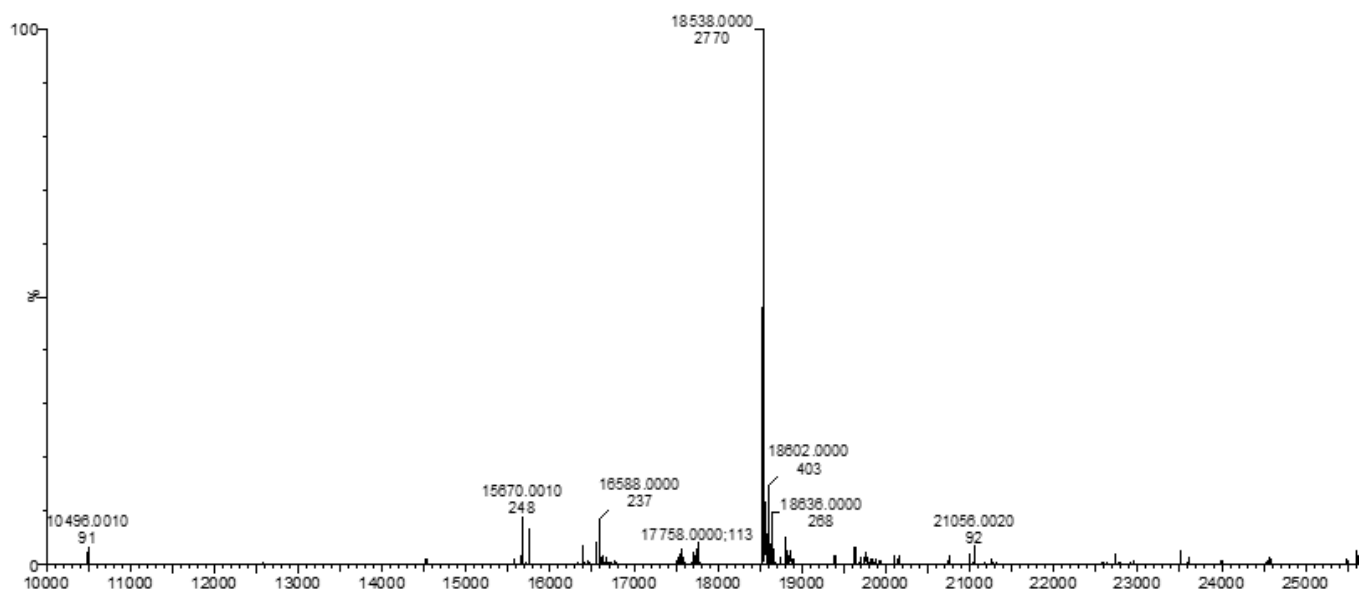

Figure 3. Mass spectrometric validation of the desired recombinant modified silk fusion protein sequence. Based on the amino acid sequence shown for S4H4 (Table 1), predicted to be 18,538.00 Da, the $\mathrm{S} 4 \mathrm{H} 4$ protein was confirmed as the predominant peak in the plot.

Following characterization of the HBM silk fusion peptide (Figures 2 and 3), functional assays were used to determine its capability to bind heparin when surface-bound (Figure 4). A dot blot assay was used to confirm the ability of surface-adsorbed, fusion protein to bind biotinylated heparin (Figure 4A). The S4H4 fusion protein was detected by biotinylated heparin, whereas SX2 and BSA (negative control) were not detected, indicating that heparin was unable to bind to either protein. Notably, Bovine Serum Albumin (BSA) has no reported ability to bind heparin [45]. An analogous blot was probed with secondary streptavidinHRP only and did not show any reaction regardless of the protein spotted (data not shown). Unfortunately, this assay format exhibited limited sensitivity: approximately $0.3 \mathrm{mg}$ of protein applied to each $10 \mu \mathrm{L}$ spot was required for detection with biotinylated heparin. Thus, an Enzyme Linked Immunosorbent Assay (ELISA) was conducted to validate the dot blot and probe the binding sensitivity. The ELISA was able to confirm that biotinylated heparin bound approximately 3-fold better to S4H4 than to SX2 or BSA (Figure 4B).

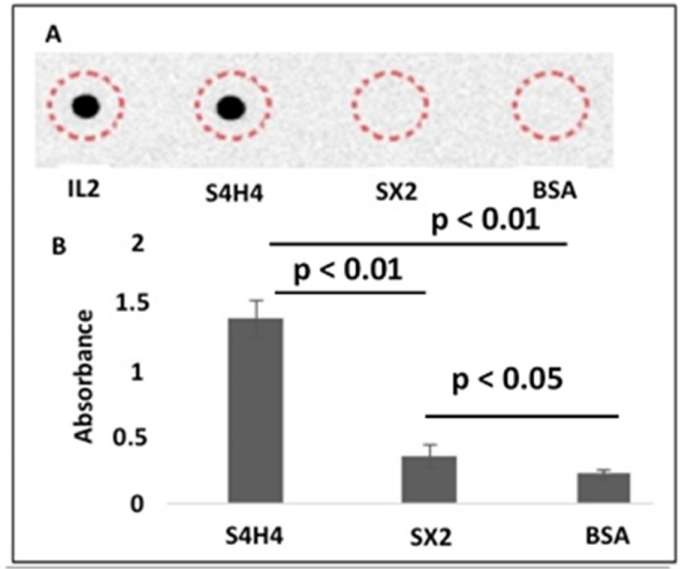

Figure 4. (A) S4H4 spotted on nitrocellulose binds heparin similar to the positive control IL-2. SX2 was unable to bind heparin, similar to the BSA negative control. A dashed circle indicates areas where each protein was spotted. (B) ELISA to detect the interaction of S4H4, SX2 and BSA (negative control) with heparin; $\mathrm{n}=4, p<0.05$. 
One powerful aspect of this unique fusion is the ability of the heparin-binding motif to not only bind heparin but also to act as an antimicrobial peptide. To assess the ability of $\mathrm{S} 4 \mathrm{H} 4$ to inhibit bacterial growth, a standard Kirby-Bauer zone of inhibition assay was performed against planktonic E. coli ATCC 12435. Silk without the heparin-binding motif (SX2) did not show a zone of clearing nor did BSA; however, $\mathrm{S} 4 \mathrm{H} 4$ produced a clear zone of inhibition (Figure 5). None of the proteins complexed with heparin in this experiment.
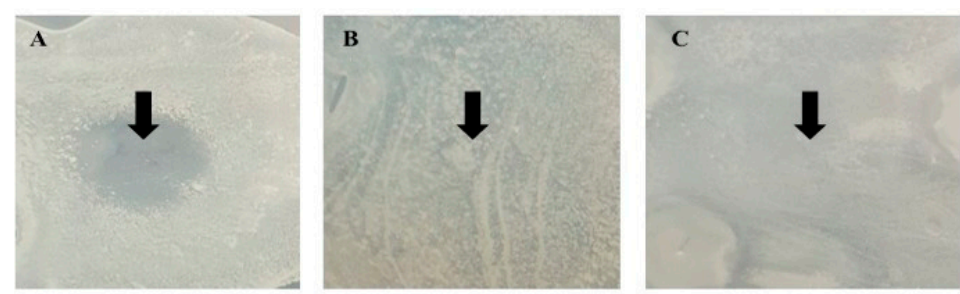

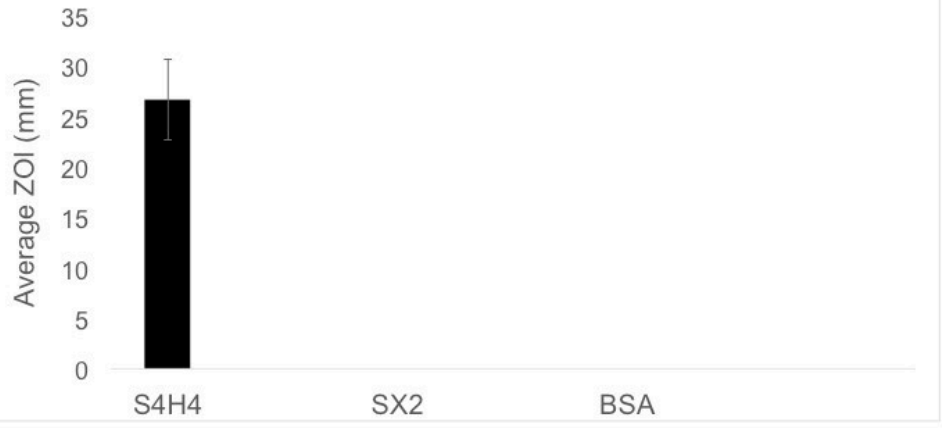

Figure 5. Zone of inhibition of fusion protein compared with other controls. (A) S4H4, (B) SX2, and (C) BSA (included as a negative control). Note that the same amount of protein was spotted (indicated by the arrow) for each sample. The average $(n=3)$ measured zone of inhibition is shown in the bar graph below the representative images. No zone of inhibition was observed for either silk or BSA controls.

In addition to the antibacterial effect on planktonic E. coli 12435, the fusion protein also prevented the growth of biofilm-like surface-adherent E. coli colonies (Figure 6) when compared to both PBS-treated and blank wells (i.e., TCPS) controls. ATCC E. coli strain 12435 is a validated biofilm-forming strain [47]. The control groups show a clear formation of biofilm with the presence of a glycocalyx as indicated by crystal violet (CV) staining (blue color) (Figure 6), whereas CV optical absorbance $(600 \mathrm{~nm})$, a standard measure of biofilm formation [48], in the presence of S4H4 is below the detectable limit of the assay and the spectrophotometer (L.O.D. 0.04 OD). Hence, S4H4 seems to have effectively prevented biofilm formation in the absence of heparin.

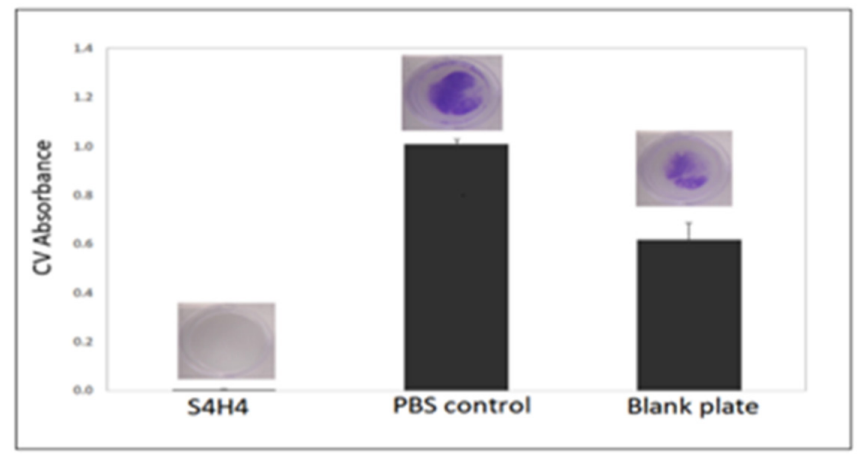

Figure 6. Crystal violet assay for biofilm formation showing that wells coated with S4H4 do not support biofilm formation, as evidenced by the lack of purple color. Alternatively, wells rinsed with PBS or the blank clearly evidenced biofilm (as indicated by optical density at $600 \mathrm{~nm}$ and presence of purple color). $(\mathrm{n}=3)$. 
While both dot blot and ELISA provide evidence that heparin can bind to S4H4, bioactivity of the silk-bound heparin was also assessed. A validated assay to determine the activated partial thromboplastin time (aPTT) as an indirect measure of clot-like formation in vitro, was performed in the presence of SX2 and S4H4 proteins. Time to visualize clot formation elicited by the calcium ion addition was confirmed as a decrease in the optical transparency of the aPTT solution reaction and formation of a clot (Figure 7). When S4H4 protein was surface coated and exposed to heparinized plasma, no clot was detected by the aPTT assay after $24 \mathrm{~h}$, similar to an uncoated microwell surface when soluble heparin only was added. However, when heparin was added to wells coated with SX2, clotting was merely delayed $(13 \pm 5 \mathrm{~min})$ when compared to SX2 control wells without heparin addition ( $9 \pm 3 \mathrm{~min}$ ) (Table 2). Regardless of the surface coating, in the absence of heparin, SX2, S4H4 and plasma all showed similar clotting times of approximately 9 min.

A

\section{+ Heparin}

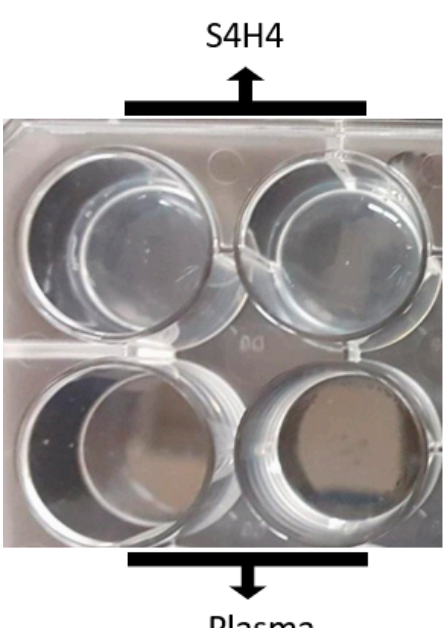

Plasma

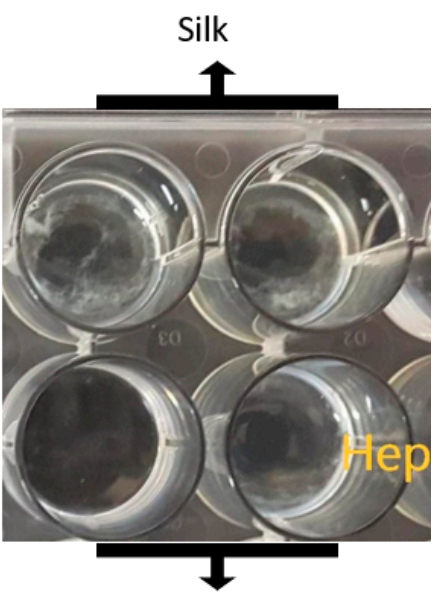

Heparin

B

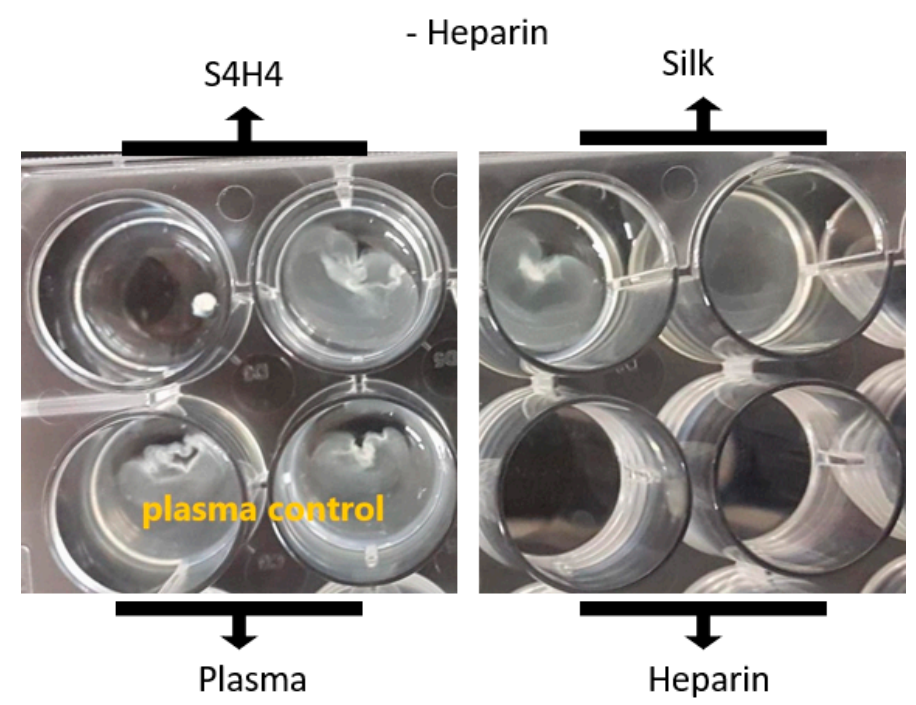

Figure 7. A visual representation of the aPTT coagulation assay endpoints. (A) heparin added to the assay produced noticeable lack of clotting in both $\mathrm{S} 4 \mathrm{H} 4$ (top left) and the plasma control (bottom left) as anticipated by their ability to bind heparin, comparable to the heparinized controls (bottom right). The silk-coated surface shows evidence of clot-like formation (top right). (B) All wells lacking heparin produced a noted strong clotting response, in contrast to control heparinized wells (bottom right) $(n=3)$. 
Table 2. A comparison of average times needed for visual clot formation either in the presence or absence of heparin.

\begin{tabular}{ccc}
\hline Sample & Heparin Added & Clotting Time (min) \\
\hline Heparin & + & No Clot \\
\hline S4H4 & + & No Clot \\
\hline SX2 & + & $13 \pm 5$ \\
\hline Plasma only & + & $30 \pm 6$ \\
\hline S4H4 & - & $9 \pm 4$ \\
\hline SX2 & - & $9 \pm 3$ \\
\hline Plasma only & - & $8 \pm 3$
\end{tabular}

Embedding the heparin-binding motif in a silk-like peptide was meant to endow a mechanically-robust structural peptide with the ability to bind heparin and prevent bacterial colonization of a surface. Although circular dichroism (CD, data not shown) of the fusion protein showed the presence of beta sheets and random coils, the percentage was lower than the natural silk, which could be due to the shorter length of the recombinant protein. Thus, to compare the physical properties of the recombinant proteins, fibers were wet spun from both the fusion protein (S4H4) and plain silk (SX2). Subsequent mechanical testing revealed that the presence of HBM in the fusion protein decreased the breaking stress from $41 \mathrm{MPa}$ to $11 \mathrm{MPa}$, but increased the breaking strain from $4.4 \%$ to $7.1 \%$ (Figure 8 ). This may be a reflection of the fiber thickness, as it is known that thicker diameter fibers impart extensibility while thinner diameters are associated with strength [49]. Nevertheless, optimizing the ratio of HBM to silk may be necessary to preserve mechanical integrity.

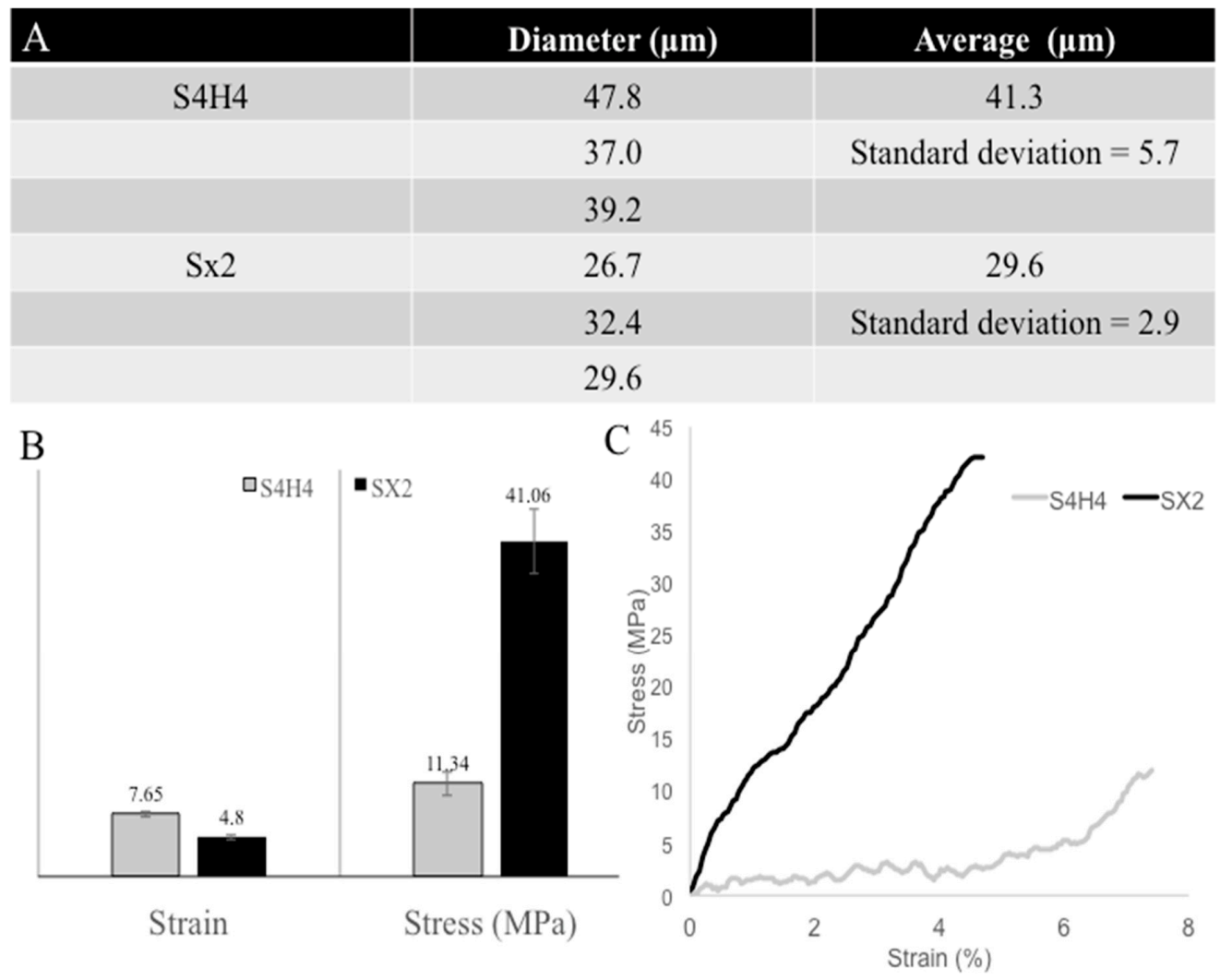

Figure 8. Comparison of the (A) wet spun fiber diameters, $($ B) average stresses and strains at breakage produced by SX2 and S4H4 fibers, and (C) an average stress/strain curve. S4H4 fibers were thick with decreased stress and increased strain compared to SX2. 


\section{Discussion}

The relative success of surface coatings in providing a versatile platform for pharmaceutical immobilization is a driving force behind the use of either biomimetic [50-52] or synthetic polymers $[53,54]$ as chemically and biologically defined surface coatings [55]. While silk's robust mechanics and limited protease sensitivity have made it an attractive surface coating, its biochemistry and structural hierarchy have made it an accessible platform for chemical and biological modifications. Furthermore, as opposed to many surface coatings (both synthetic and biological) that provoke a robust foreign body response, the well-documented biocompatibility of silk [56] adds to its allure, particularly for bloodcontacting biomaterial applications. Previously, several groups have explored heparin-silk complexes by chemically linking heparin to silkworm silk (a more readily available yet mechanically inferior variety of silk) or via blending or mixing prior to processing by electrospinning or film casting [57-59]. Heparin grafted either electrostatically or covalently [60] to silk-based vascular scaffolds showed that heparin grafted at a density of $1.48 \pm 0.19 \mathrm{mg} / \mathrm{cm}^{2}$ was able to improve the in vitro anticoagulant effect of the silk for up to 12-weeks [61]. Despite these promising results, heparin chemically grafted to a silk surface may suffer the same fate in vivo as most other heparinized surfaces: rapid silencing of bioactivity by host protein biofouling. In the current study, the natural binding partner of heparin was genetically linked to a spider silk motif (Table 1, Figures 2 and 3, Supplementary Figure S1). It was clear from the data that the $\mathrm{S} 4 \mathrm{H} 4$ fusion protein was capable of binding heparin from a solution (Figure 4). We hypothesize that by using heparin's binding partner instead of a chemical linkage to heparin itself, a "self-renewing", heparinenriched surface coating can be created. This new strategy represents a novel method that relies on the biochemistry of receptor-ligand interactions to shunt the coagulation cascade $[59,60]$.

The theoretical "self-renewing" nature of a surface-coating produced using the reported fusion protein $\mathrm{S} 4 \mathrm{H} 4$, which is driven by the kinetics of heparin binding, addresses one of the biggest hurdles to the efficacy of heparinized surfaces: bioactivity silencing due to protein biofouling. Although a full evaluation of the precise kinetics and stability of binding are beyond the scope of this initial in vitro study, it was noted that by varying the wash time following heparin adsorption in the aPTT assay, the ability of heparin to prevent clot formation was altered; more rigorous washing (three times for 1 min each) led to a loss of anti-coagulant activity presumably due to the loss of heparin. This supposition was confirmed via x-ray photoelectron spectroscopy (XPS, Supplementary Table S1), which showed an increase in nitrogen content and decrease in silicon after the addition of the protein, consistent with the adherent protein adsorbed layer, and a loss of protein after rigorous washing by re-appearance of these XPS protein-relevant signals. The kinetics of binding are expected to be very different in in vitro assessments of our $\mathrm{S} 4 \mathrm{H} 4$ fusion based on the ionic strength of the assay solutions and may offer little overall relevance to the translatability of the fusion in vivo in the presence of endogenous heparins. Irrespective of the kinetics, the ability to bind heparin was not evident under any conditions considered with adsorbed SX2 or BSA negative controls (Figure 4B). Expression of the HBM peptide alone in the absence of the MaSp2 silk peptide as a positive control was not feasible (data not shown) in any measurable quantity. This is likely due to the high molar percent of lysine in the peptide and the specific bacteria's innate ability to respond to this AMP [62,63]. Thus, the HBM peptide was expressed only as a fusion stabilized by silk.

Independent of techniques applied to determine protein ligand affinity and stability, the ionic strength of the various buffers should be considered in both binding and functional assays. Based on the nature of heparin's molecular interactions, the ionic environment of the $\mathrm{S} 4 \mathrm{H} 4$ fusion peptide could potentially reduce or disrupt the predominant electrostatic interactions [64] between negatively charged heparin and its positively charged protein binding partners. With over 20,000 different non-specific blood proteins and a $320 \mathrm{mOsm}$ solute concentration, the substantial ionic strength of blood seems to control the specificity of natural heparin interactions $[65,66]$. This may indicate that a level of specificity governs 
the interaction of heparin beyond mere electrostatic interactions; a theory that was recently explored in the literature [67] and peripherally considered in this study. Additionally, ionic interactions may not only play a role in heparin binding and consequently anticoagulation bioactivity, but may also influence the antimicrobial activity of the HBM. In our currently study, ELISAs for heparin-silk motif complexation were run with both desalted and buffered (Maxwell elution buffer, $500 \mathrm{mM}$ imidazole, $100 \mathrm{mM}$ HEPES, pH 7.5) samples with no significant differences in assay performance (data not shown), indicating that in the current study, the range of ionic strengths based on buffer composition did not alter heparin binding to HBM in S4H4 or presumably hinder interaction with SX2 or BSA controls.

Not only does incorporation of the heparin binding motif into a MaSp2 silk background provide the potential for a "self-renewing" heparin-enriched surface, but it also affords the dual functionality of being anti-coagulating and simultaneously anti-microbial. In an effort to characterize the anti-coagulant nature of the S4H4-HBM fusion protein, activated partial thromboplastin time (aPTT) assay, providing an indirect measure of coagulation (Figure 7 and Table 2), showed that rat plasma coagulation times were altered. Using this assay, the $\mathrm{S} 4 \mathrm{H} 4$ fusion protein was asserted to bind heparin to provide functional equivalence to heparin alone, indicating that the HBM portion of the fusion not only bound heparin (as previously confirmed), but also presented heparin in a functional conformation, at least in the intrinsic and common coagulation pathways. Clotting was only slightly delayed (from 9 min to 13 min, Table 2) when SX2 was exposed to heparin, confirming that anticoagulant effects were primarily attributed to the addition of HBM and not the MaSp2 silk component. Regardless of the protein in each assay well, in the absence of heparin, clot formation occurred approximately 9 min after the addition of calcium chloride to the assay to chelate the sodium citrate anti-coagulant used during collection.

In addition to the ability of our new silk-HBM fusion construct to bind functional heparin, $\mathrm{S} 4 \mathrm{H} 4$ was designed to act as an antimicrobial coating. The antimicrobial efficacy of the heparin-binding motif is based on its Antimicrobial Peptide (AMP)-like residues and structure. HBM includes a common motif component (XBBXBX, where $X$ represents hydrophobic or uncharged amino acids, and $B$ represents basic amino acids) that folds as an amphipathic helical structure with approximately $20 \AA$ between basic amino acids [68]. While recent evidence suggests a diversity of mechanisms based on the peptide sequence of the AMP but also AMP/bacterial pairings [69,70], the AMP structure remains important. The classic proposed mechanism of action suggests that AMP exerts bactericidal effects by disrupting the outer microbial member to create pores [69,71], without a specific target [68]. This action would seem to necessitate a soluble, amphoteric species, a supposition at odds with the proposed surface-bound use of the HBM silk fusion explored in this study. Nevertheless, based on a standard Kirby Bauer zone of inhibition assay (Figure 5) as well as a crystal violet biofilm assay (Figure 6), silk modified with HBM reduces the proliferation of both planktonic (Figure 5) and adherent (Figure 6) E. coli 12435 bacteria. Thus, a more accurate predicted HBM mechanism of action may be based on the imperfect amphiphilic nature of the molecule, which may facilitate disruption of the bacterial membrane. Under this proposed mechanism, surface-bound HBM may prove more effective against sessile than planktonic pathogens. Confirmation of this mechanism requires further detailed structural and mechanistic studies with the silk fusion peptide.

The final consideration when interpreting the antimicrobial efficacy of S4H4 may be the length of the HBM element. The HBM chosen in this study is comprised of eight amino acids, with choice driven largely by the reported disassociation kinetics with heparin. However, it is unclear if a minimum peptide length is necessary for AMP activity. Liu et al. investigated the influence of AMP length on the hemolytic and antimicrobial activity of a model AMP, Arg-Trp (RW). The study found that $(\mathrm{RW})_{3}$, a 6-amino acid peptide, was the optimal length for both efficiency in synthesis and antibacterial activity [72]. These results must be reconsidered when applying them to the current design, which includes a combination of Arg, Ala, and Lys. Inclusion of the aromatic amino acid Trp in the study by Liu and its absence in our study may significantly impact the relevance of the Liu analysis. 
Moreover, in the current AMP-like peptide, Ala and Arg, which can promote binding of heparin [73] but may prove otherwise disruptive when trying to preserve the mechanics of silk, need to be somewhat limited to balance the mechanics and desired anticoagulant function. Similarly, the presence of Pro in the MaSp2 silk portion of the fusion protein is generally considered disruptive to binding heparin, [27] but may play an important role in enhancing the efficacy of the AMP-like functionality [69], offering further constraints to the design.

The presence of Pro in MaSp2 is essential to maintain the balance of strength and elasticity [41]. Based on anticipated intermolecular hydrogen bonding [74], two polymerized MaSp2 silk monomers were predicted to provide a sufficient mechanical background to embed HBM and subsequently bind heparin with minimal steric hindrance. However, it is clear from the tensile testing (Figure 8) that the presence of HBM reduced the fiber strength while enhancing its extensibility. Although this may be attributed to the well-documented phenomena that larger diameter fibers are generally more extensible, the large deviations would negate this as being the sole cause of the effect. Instead, we would posit that the basic and cationic charges present in the HBM elements of S4H4 may disrupt intrinsic silk hydrogen bonding and hydrophobic interactions. Disruption of these critical forces may negatively affect the packing efficiency and alignment of the protein, effectively reducing the strength of the resulting fiber. Ultimately, having a heparin-binding, silk-based protein with increased extensibility and decreased tensile strength may prove beneficial as a biomaterial surface coating.

\section{Conclusions}

A new protein fusion comprising spider silk-derived MaSp2 peptides genetically linked with a consensus heparin-binding peptide was shown to bind heparin both at a surface and in buffer solution. This fusion protein was shown to exhibit affinity for complexing soluble heparin, demonstrated under certain in vitro conditions (e.g., ELISA and dot blot assay). However, the precise complex stoichiometry and heparin binding kinetics remain undetermined. Bound heparin anticoagulant activity was shown in an aPTT assay with rat plasma, an indirect coagulation in vitro assay. Furthermore the S4H4 fusion protein also demonstrated in vitro antimicrobial activity against both planktonic and adherent E. coli ATCC 12435 cultures using zone of inhibition and crystal violet assays. This newly engineered chimera protein with its ability to bind heparin as well as its intrinsic antimicrobial potential can be utilized as a new biomedical material coating, potentially on hemodialysis catheters.

Supplementary Materials: The following supporting information can be downloaded at https: / / www.mdpi.com/article/10.3390/bioengineering9020046/s1; Figure S1: HPLC analysis of both the recombinant MaSp2 silk protein (flat grey line) and the s2H4 chimera protein (black peak). Each protein was derivatized with OPA to detect an increase in the number of primary amines present in the proteins. Notice the distinct peak at $32 \mathrm{~min}$ for the chimera that is absent in the silk protein, indicating an increase in primary amines as a result of the lysine residues in the HBM portion of the protein. Table S1: XPS analysis of the $\mathrm{S}_{4} \mathrm{H}_{4}$ coated wells after rinsing with the buffer showed an increase in the nitrogen content compared to the uncoated wells.

Author Contributions: Data curation, D.W.G.; Formal analysis, P.M., D.D., N.B. and S.J.S.; Funding acquisition, A.E.B.; Methodology, K.K., P.M. and D.D.; Project administration, D.W.G. and A.E.B.; Resources, A.E.B.; Software, P.M.; Writing-original draft, P.M. and D.D. All authors have read and agreed to the published version of the manuscript.

Funding: This research was supported by NIH grant R21 DK088426-01 (to D.W.G. and A.E.B. at the University of Utah) and by start-up funds provided to A.E.B. from North Dakota State University's Department of Pharmaceutical Sciences. Funding for the Core Synthesis and Analytical Services Facility used in this publication was made possible by NIH Grant P30 GM103332 (NIGMS).

Institutional Review Board Statement: Not Applicable. 
Informed Consent Statement: Not Applicable.

Data Availability Statement: Not Applicable.

Acknowledgments: We thank R. Campbell (Utah) for his input on using biotinylated heparin, K. Hill (NDSU) for assistance with protein production, J. Bahr for XPS study and B. Hoffmann for assistance with mechanical testing. Manuscript contents are solely the responsibility of the authors and do not necessarily represent the official views of the NIH.

Conflicts of Interest: The authors declare no conflict of interest.

\author{
Abbreviation \\ S4H4 fusion protein containing four repetitive units of silk and four repetitive units of heparin \\ binding peptide \\ SX2 two repetitive units of silk \\ HBM heparin binding motif \\ AMP antimicrobial peptide
}

\title{
References
}

1. Brooks, A.E.; Nelson, S.R.; Jones, J.A.; Koenig, C.; Hinman, M.; Stricker, S.; Lewis, R.V. Distinct contributions of model MaSp1 and MaSp2 like peptides to the mechanical properties of synthetic major ampullate silk fibers as revealed in silico. Nanotechnol. Sci. Appl. 2008, 1, 9-16. [CrossRef]

2. Hinman, M.B.; Jones, J.A.; Lewis, R.V. Synthetic spider silk: A modular fiber. Trends Biotechnol. 2000, 18, 374-379. [CrossRef]

3. Chaw, R.C.; Correa-Garhwal, S.M.; Clarke, T.H.; Ayoub, N.A.; Hayashi, C.Y. Proteomic Evidence for Components of Spider Silk Synthesis from Black Widow Silk Glands and Fibers. J. Proteome Res. 2015, 14, 4223-4231. [CrossRef]

4. Holland, G.P.; Jenkins, J.E.; Creager, M.S.; Lewis, R.V.; Yarger, J.L. Solid-state NMR investigation of major and minor ampullate spider silk in the native and hydrated states. Biomacromolecules 2008, 9, 651-657. [CrossRef]

5. $\quad$ Blamires, S.J.; Tseng, Y.-H.; Wu, C.-L.; Toft, S.; Raubenheimer, D.; Tso, I.-M. Spider web and silk performance landscapes across nutrient space. Sci. Rep. 2016, 6, 26383. [CrossRef] [PubMed]

6. Hayashi, C.Y.; Shipley, N.H.; Lewis, R.V. Hypotheses that correlate the sequence, structure, and mechanical properties of spider silk proteins. Int. J. Biol. Macromol. 1999, 24, 271-275. [CrossRef]

7. $\quad$ Creager, M.S.; Jenkins, J.E.; Thagard-Yeaman, L.A.; Brooks, A.E.; Jones, J.A.; Lewis, R.V.; Holland, G.P.; Yarger, J.L. Solid-State NMR Comparison of Various Spiders' Dragline Silk Fiber. Biomacromolecules 2010, 11, 2039-2043. [CrossRef]

8. Yazawa, K.; Yamaguchi, E.; Knight, D.; Asakura, T. ${ }^{13} \mathrm{C}$ solid-state NMR study of the ${ }^{13} \mathrm{C}-$ labeled peptide, $(\mathrm{E})_{8}$ GGLGGQGAG(A) 6 GGAGQGGYGG as a model for the local structure of Nephila clavipes dragline silk (MaSp1) before and after spinning. Biopolymers 2012, 97, 347-354. [CrossRef]

9. Ohgo, K.; Bagusat, F.; Asakura, T.; Scheler, U. Investigation of structural transition of regenerated silk fibroin aqueous solution by Rheo-NMR spectroscopy. J. Am. Chem. Soc. 2008, 130, 4182-4186. [CrossRef]

10. Xiao, H.; Miller, S.J.; Bang, N.U.; Faulk, W.P. Protein-bound heparin/heparan sulfates in human adult and umbilical cord plasma. Haemostasis 1999, 29, 237-246. [CrossRef]

11. Krishnaji, S.T.; Kaplan, D.L. Bioengineered chimeric spider silk-uranium binding proteins. Macromol. Biosci. 2013, 13, 256-264. [CrossRef]

12. Gomes, S.; Gallego-Llamas, J.; Leonor, I.B.; Mano, J.F.; Reis, R.L.; Kaplan, D.L. Biological responses to spider silk-antibiotic fusion protein. J. Tissue Eng. Regen. Med. 2012, 6, 356-368. [CrossRef]

13. Canabady-Rochelle, L.L.; Belton, D.J.; Deschaume, O.; Currie, H.A.; Kaplan, D.L.; Perry, C.C. Bioinspired Silicification of SilicaBinding Peptide-Silk Protein Chimeras: Comparison of Chemically and Genetically Produced Proteins. Biomacromolecules 2012, 13, 683-690. [CrossRef]

14. Wong Po Foo, C.; Patwardhan, S.V.; Belton, D.J.; Kitchel, B.; Anastasiades, D.; Huang, J.; Naik, R.R.; Perry, C.C.; Kaplan, D.L. Novel nanocomposites from spider silk-silica fusion (chimeric) proteins. Proc. Natl. Acad. Sci. USA 2006, 103, 9428-9433. [CrossRef] [PubMed]

15. Gomes, S.; Numata, K.; Leonor, I.B.; Mano, J.F.; Reis, R.L.; Kaplan, D.L. AFM Study of Morphology and Mechanical Properties of a Chimeric Spider Silk and Bone Sialoprotein Protein for Bone Regeneration. Biomacromolecules 2011, 12, 1675-1685. [CrossRef]

16. Scheller, J.; Henggeler, D.; Viviani, A.; Conrad, U. Purification of Spider Silk-elastin from Transgenic Plants and Application for Human Chondrocyte Proliferation. Transgenic Res. 2004, 13, 51-57. [CrossRef] [PubMed]

17. Wang, J.; Hu, W.; Liu, Q.; Zhang, S. Dual-functional composite with anticoagulant and antibacterial properties based on heparinized silk fibroin and chitosan. Colloids Surf. B Biointerfaces 2011, 85, 241-247. [CrossRef]

18. Yu, H.; Muñoz, E.M.; Edens, R.E.; Linhardt, R.J. Heparin Regulation of the Complement System. In Chemistry and Biology of Heparin and Heparan Sulfate; Elsevier: Amsterdam, The Netherlands, 2005; pp. 313-343. ISBN 978-0-08-044859-6. 
19. Diekjürgen, D.; Grainger, D.W. Polysaccharide matrices used in 3D in vitro cell culture systems. Biomaterials 2017, 141, 96-115. [CrossRef] [PubMed]

20. Edward Conrad, H. Chapter 1-Heparin vs. Heparan Sulfate. In Heparin-Binding Proteins; Edward Conrad, H., Ed.; Academic Press: San Diego, CA, USA, 1998; pp. 1-5. ISBN 978-0-12-186060-8.

21. Edward Conrad, H. Chapter 8-Heparin-Binding Proteins in Hemostasis. In Heparin-Binding Proteins; Edward Conrad, H., Ed.; Academic Press: San Diego, CA, USA, 1998; pp. 239-300. ISBN 978-0-12-186060-8.

22. Edward Conrad, H. Chapter 4-Structural Modification of Heparinoids. In Heparin-Binding Proteins; Edward Conrad, H., Ed.; Academic Press: San Diego, CA, USA, 1998; pp. 115-136. ISBN 978-0-12-186060-8.

23. Edward Conrad, H. Chapter 6-Heparinoid/Protein Interactions. In Heparin-Binding Proteins; Edward Conrad, H., Ed.; Academic Press: San Diego, CA, USA, 1998; pp. 183-202. ISBN 978-0-12-186060-8.

24. Cardin, A.D.; Weintraub, H.J. Molecular modeling of protein-glycosaminoglycan interactions. Arterioscler. Off. J. Am. Heart Assoc. Inc. 1989, 9, 21-32. [CrossRef] [PubMed]

25. Pasupuleti, M.; Schmidtchen, A.; Malmsten, M. Antimicrobial peptides: Key components of the innate immune system. Crit. Rev. Biotechnol. 2012, 32, 143-171. [CrossRef]

26. Martins, M.C.L.; Curtin, S.A.; Freitas, S.C.; Salgueiro, P.; Ratner, B.D.; Barbosa, M.A. Molecularly designed surfaces for blood deheparinization using an immobilized heparin-binding peptide. J. Biomed. Mater. Res. Part A 2009, 88, 162-173. [CrossRef] [PubMed]

27. Verrecchio, A.; Germann, M.W.; Schick, B.P.; Kung, B.; Twardowski, T.; Antonio, J.D.S. Design of Peptides with High Affinities for Heparin and Endothelial Cell Proteoglycans. J. Biol. Chem. 2000, 275, 7701-7707. [CrossRef] [PubMed]

28. Malmsten, M.; Kasetty, G.; Pasupuleti, M.; Alenfall, J.; Schmidtchen, A. Highly Selective End-Tagged Antimicrobial Peptides Derived from PRELP. PLoS ONE 2011, 6, e16400. [CrossRef]

29. Lee, J.-Y.; Choo, J.-E.; Choi, Y.-S.; Lee, K.-Y.; Min, D.-S.; Pi, S.-H.; Seol, Y.-J.; Lee, S.-J.; Jo, I.-H.; Chung, C.-P.; et al. Characterization of the surface immobilized synthetic heparin binding domain derived from human fibroblast growth factor-2 and its effect on osteoblast differentiation. J. Biomed. Mater. Res. Part A 2007, 83, 970-979. [CrossRef] [PubMed]

30. Vepari, C.; Matheson, D.; Drummy, L.; Naik, R.; Kaplan, D.L. Surface modification of silk fibroin with poly(ethylene glycol) for antiadhesion and antithrombotic applications. J. Biomed. Mater. Res. Part A 2010, 93, 595-606. [CrossRef]

31. Wang, X.; Zhang, X.; Castellot, J.; Herman, I.; Iafrati, M.; Kaplan, D.L. Controlled release from multilayer silk biomaterial coatings to modulate vascular cell responses. Biomaterials 2008, 29, 894-903. [CrossRef]

32. Panilaitis, B.; Altman, G.H.; Chen, J.; Jin, H.J.; Karageorgiou, V.; Kaplan, D.L. Macrophage responses to silk. Biomaterials 2003, 24, 3079-3085. [CrossRef]

33. Wang, Y.; Kim, H.-J.; Vunjak-Novakovic, G.; Kaplan, D.L. Stem cell-based tissue engineering with silk biomaterials. Biomaterials 2006, 27, 6064-6082. [CrossRef]

34. Nagaoka, M.; Jiang, H.-L.; Hoshiba, T.; Akaike, T.; Cho, C.-S. Application of recombinant fusion proteins for tissue engineering. Ann. Biomed. Eng. 2010, 38, 683-693. [CrossRef]

35. Gomes, S.; Leonor, I.B.; Mano, J.F.; Reis, R.L.; Kaplan, D.L. Antimicrobial functionalized genetically engineered spider silk Biomaterials 2011, 32, 4255-4266. [CrossRef]

36. Belton, D.J.; Mieszawska, A.J.; Currie, H.A.; Kaplan, D.L.; Perry, C.C. Silk-silica composites from genetically engineered chimeric proteins: Materials properties correlate with silica condensation rate and colloidal stability of the proteins in aqueous solution. Langmuir ACS J. Surf. Colloids 2012, 28, 4373-4381. [CrossRef] [PubMed]

37. Bini, E.; Foo, C.W.P.; Huang, J.; Karageorgiou, V.; Kitchel, B.; Kaplan, D.L. RGD-Functionalized Bioengineered Spider Dragline Silk Biomaterial. Biomacromolecules 2006, 7, 3139-3145. [CrossRef] [PubMed]

38. Appelgren, P.; Ransjö, U.; Bindslev, L.; Espersen, F.; Larm, O. Surface heparinization of central venous catheters reduces microbial colonization in vitro and in vivo: Results from a prospective, randomized trial. Crit. Care Med. 1996, 24, 1482-1489. [CrossRef] [PubMed]

39. Maxwell 16 Polyhistidine Protein Purification Kit Automated Protein Purification with Maximum Performance and Convenience. Available online: https://www.promega.com/resources/pubhub/promega-notes-2007/maxwell-16-polyhistidine-purificationkit-automated-protein-purification-with-maximum-performance/ (accessed on 7 December 2019).

40. Teulé, F.; Cooper, A.R.; Furin, W.A.; Bittencourt, D.; Rech, E.L.; Brooks, A.; Lewis, R.V. A protocol for the production of recombinant spider silk-like proteins for artificial fiber spinning. Nat. Protoc. 2009, 4, 341-355. [CrossRef] [PubMed]

41. Brooks, A.E.; Stricker, S.M.; Joshi, S.B.; Kamerzell, T.J.; Middaugh, C.R.; Lewis, R.V. Properties of Synthetic Spider Silk Fibers Based on Argiope aurantia MaSp2. Biomacromolecules 2008, 9, 1506-1510. [CrossRef]

42. Najjam, S.; Mulloy, B.; Theze, J.; Gordon, M.; Gibbs, R.; Rider, C.C. Further characterization of the binding of human recombinant interleukin 2 to heparin and identification of putative binding sites. Glycobiology 1998, 8, 509-516. [CrossRef] [PubMed]

43. Raghavan, S.A.V.; Dikshit, M. Recent advances in the status and targets of antithrombotic agents. Drugs Future 2002, 27, 669-688. [CrossRef]

44. Hattori, T.; Kimura, K.; Seyrek, E.; Dubin, P.L. Binding of bovine serum albumin to heparin determined by turbidimetric titration and frontal analysis continuous capillary electrophoresis. Anal. Biochem. 2001, 295, 158-167. [CrossRef] [PubMed] 
45. Kugel, A.J.; Jarabek, L.E.; Daniels, J.W.; Vander Wal, L.J.; Ebert, S.M.; Jepperson, M.J.; Stafslien, S.J.; Pieper, R.J.; Webster, D.C.; Bahr, J.; et al. Combinatorial materials research applied to the development of new surface coatings XII: Novel, environmentally friendly antimicrobial coatings derived from biocide-functional acrylic polyols and isocyanates. J. Coat. Technol. Res. 2009, 6, 107-121. [CrossRef]

46. Stafslien, S.; Daniels, J.; Chisholm, B.; Christianson, D. Combinatorial materials research applied to the development of new surface coatings III. Utilisation of a high-throughput multiwell plate screening method to rapidly assess bacterial biofilm retention on antifouling surfaces. Biofouling 2007, 23, 37-44. [CrossRef]

47. Wu, H.; Moser, C.; Wang, H.-Z.; Høiby, N.; Song, Z.-J. Strategies for combating bacterial biofilm infections. Int. J. Oral Sci. 2015, 7, 1-7. [CrossRef]

48. Adetunji, V.O.; Isola, T.O. Crystal Violet Binding Assay for Assessment of Biofilm Formation by Listeria monocytogenes and Listeria spp. on Wood, Steel and Glass Surfaces. Glob. Vet. 2011, 6, 6-10.

49. Hoffmann, B.; Gruat-Henry, C.; Mulinti, P.; Jiang, L.; Brooks, B.D.; Brooks, A.E. Using Hydrodynamic Focusing to Predictably Alter the Diameter of Synthetic Silk Fibers. PLoS ONE 2018, 13, e0195522. Available online: https:/ /journals.plos.org/plosone/ article?id=10.1371/journal.pone.0195522 (accessed on 7 December 2019). [CrossRef]

50. Kairaitis, L.K.; Gottlieb, T. Outcome and complications of temporary haemodialysis catheters. Nephrol. Dial. Transplant. Off. Publ. Eur. Dial. Transpl. Assoc.-Eur. Ren. Assoc. 1999, 14, 1710-1714. [CrossRef]

51. Stigter, M.; Bezemer, J.; de Groot, K.; Layrolle, P. Incorporation of different antibiotics into carbonated hydroxyapatite coatings on titanium implants, release and antibiotic efficacy. J. Control. Release Off. J. Control. Release Soc. 2004, 99, 127-137. [CrossRef] [PubMed]

52. Harbers, G.M.; Emoto, K.; Greef, C.; Metzger, S.W.; Woodward, H.N.; Mascali, J.J.; Grainger, D.W.; Lochhead, M.J. A functionalized poly(ethylene glycol)-based bioassay surface chemistry that facilitates bio-immobilization and inhibits non-specific protein, bacterial, and mammalian cell adhesion. Chem. Mater. Publ. Am. Chem. Soc. 2007, 19, 4405-4414. [CrossRef]

53. Hendricks, S.K.; Kwok, C.; Shen, M.; Horbett, T.A.; Ratner, B.D.; Bryers, J.D. Plasma-deposited membranes for controlled release of antibiotic to prevent bacterial adhesion and biofilm formation. J. Biomed. Mater. Res. 2000, 50, 160-170. [CrossRef]

54. Rojas, I.A.; Slunt, J.B.; Grainger, D.W. Polyurethane coatings release bioactive antibodies to reduce bacterial adhesion. J. Control. Release Off. J. Control. Release Soc. 2000, 63, 175-189. [CrossRef]

55. Ghandehari, H. Recombinant biomaterials for pharmaceutical and biomedical applications. Pharm. Res. 2008, 25, 672-673. [CrossRef] [PubMed]

56. Vepari, C.; Kaplan, D.L. Silk as a Biomaterial. Prog. Polym. Sci. 2007, 32, 991-1007. [CrossRef]

57. Elahi, M.F.; Guan, G.; Wang, L.; Zhao, X.; Wang, F.; King, M.W. Surface Modification of Silk Fibroin Fabric Using Layer-by-Layer Polyelectrolyte Deposition and Heparin Immobilization for Small-Diameter Vascular Prostheses. Langmuir 2015, 31, 2517-2526. [CrossRef] [PubMed]

58. Cestari, M.; Muller, V.; da Rodrigues, J.H.S.; Nakamura, C.V.; Rubira, A.F.; Muniz, E.C. Preparing silk fibroin nanofibers through electrospinning: Further heparin immobilization toward hemocompatibility improvement. Biomacromolecules 2014, 15, $1762-1767$. [CrossRef]

59. Seib, F.P.; Herklotz, M.; Burke, K.A.; Maitz, M.F.; Werner, C.; Kaplan, D.L. Multifunctional silk-heparin biomaterials for vascular tissue engineering applications. Biomaterials 2014, 35, 83-91. [CrossRef]

60. Liu, Z.; Li, G.; Zheng, Z.; Li, Y.; Han, Y.; Kaplan, D.L.; Wang, X. Silk fibroin-based woven endovascular prosthesis with heparin surface modification. J. Mater. Sci. Mater. Med. 2018, 29, 1-13. [CrossRef]

61. Zamani, M.; Khafaji, M.; Naji, M.; Vossoughi, M.; Alemzadeh, I.; Haghighipour, N. A Biomimetic Heparinized Composite Silk-Based Vascular Scaffold with sustained Antithrombogenicity. Sci. Rep. 2017, 7, 4455. [CrossRef]

62. Li, Y. Recombinant production of antimicrobial peptides in Escherichia coli: A review. Protein Expr. Purif. 2011, 80, 260-267. [CrossRef]

63. Zorko, M.; Jerala, R. Production of recombinant antimicrobial peptides in bacteria. Methods Mol. Biol. Clifton N.J. 2010, 618, 61-76. [CrossRef]

64. Muñoz, E.M.; Linhardt, R.J. Heparin-Binding Domains in Vascular Biology. Arterioscler. Thromb. Vasc. Biol. 2004, $24,1549-1557$. [CrossRef]

65. Ponomarenko, E.A.; Poverennaya, E.V.; Ilgisonis, E.V.; Pyatnitskiy, M.A.; Kopylov, A.T.; Zgoda, V.G.; Lisitsa, A.V.; Archakov, A.I. The Size of the Human Proteome: The Width and Depth. Int. J. Anal. Chem. 2016, 2016, 7436849. [CrossRef] [PubMed]

66. Osmolarity-An Overview I ScienceDirect Topics. Available online: https://www.sciencedirect.com/topics/immunology-andmicrobiology / osmolarity (accessed on 15 March 2019).

67. Meneghetti, M.C.Z.; Hughes, A.J.; Rudd, T.R.; Nader, H.B.; Powell, A.K.; Yates, E.A.; Lima, M.A. Heparan sulfate and heparin interactions with proteins. J. R. Soc. Interface 2015, 12, 20150589. [CrossRef]

68. Andersson, E.; Rydengård, V.; Sonesson, A.; Mörgelin, M.; Björck, L.; Schmidtchen, A. Antimicrobial activities of heparin-binding peptides. Eur. J. Biochem. 2004, 271, 1219-1226. [CrossRef]

69. Choi, H.; Rangarajan, N.; Weisshaar, J.C. Lights, Camera, Action! Antimicrobial Peptide Mechanisms Imaged in Space and Time. Trends Microbiol. 2016, 24, 111-122. [CrossRef]

70. Bechinger, B.; Gorr, S.-U. Antimicrobial Peptides: Mechanisms of Action and Resistance. J. Dent. Res. 2017, 96, 254-260. [CrossRef] [PubMed] 
71. Xiao, M.; Jasensky, J.; Foster, L.; Kuroda, K.; Chen, Z. Monitoring Antimicrobial Mechanisms of Surface-Immobilized Peptides in Situ. Langmuir 2018, 34, 2057-2062. [CrossRef]

72. Liu, Z.; Brady, A.; Young, A.; Rasimick, B.; Chen, K.; Zhou, C.; Kallenbach, N.R. Length Effects in Antimicrobial Peptides of the (RW)n Series. Antimicrob. Agents Chemother. 2007, 51, 597-603. [CrossRef] [PubMed]

73. Stenlund, P.; Lindberg, M.J.; Tibell, L.A.E. Structural Requirements for High-Affinity Heparin Binding: Alanine Scanning Analysis of Charged Residues in the C-Terminal Domain of Human Extracellular Superoxide Dismutase. Biochemistry 2002, 41, 3168-3175. [CrossRef] [PubMed]

74. Knowles, T.P.; Fitzpatrick, A.W.; Meehan, S.; Mott, H.R.; Vendruscolo, M.; Dobson, C.M.; Welland, M.E. Role of intermolecular forces in defining material properties of protein nanofibrils. Science 2007, 318, 1900-1903. [CrossRef] [PubMed] 